\title{
The Tourism Industry: An Overview
}

\author{
By Mark Anthony Camilleri' ${ }^{1}$, PhD (Edinburgh)
}

This is a pre-publication version of a chapter that was accepted by Springer Nature.

How to Cite: Camilleri, M. A. (2018). The Tourism Industry: An Overview. In Travel Marketing, Tourism Economics and the Airline Product (Chapter 1, pp. 3-27). Cham, Switzerland: Springer Nature.

\begin{abstract}
This chapter introduces its readers to the concept of tourism. It sheds light on the rationale for tourism, as it explains the tourists' inherent motivations to travel. It also describes different aspects that together make up the tourism industry. Tourists travel to destinations that are accessible to them. They require accommodation if they are visiting a place for more than twenty-four hours. Leisure and business travellers may also visit attractions and engage in recreational activities. Hence, the tourist destinations should have the right amenities and facilities. In this light, this chapter clarifies how destinations may offer different products to satisfy a wide array of tourists. Tourism products can include; urban (or city) tourism, seaside tourism, rural tourism, ecotourism, wine tourism, culinary tourism, health tourism, medical tourism, religious tourism, cultural (or heritage) tourism, sports tourism, educational tourism, business tourism (including meetings, incentives, conferences and events), among others. In conclusion, this chapter lists major points of interest in North America to clarify how diverse destinations may be appealing to different tourists, for many reasons.
\end{abstract}

\subsection{Introduction}

This chapter describes the main sectors within the travel, tourism and hospitality industries. It provides a good overview of the vertical and horizontal inter-relationships between different

\footnotetext{
${ }^{1}$ Department of Corporate Communication, Faculty of Media and Knowledge Sciences, University of Malta, Malta. Email: mark.a.camilleri@um.edu.mt
} 
sectors. Firstly, this chapter describes the nature of tourism and the individuals' inherent motivations to travel. Secondly, it distinguishes the constituent parts that make up the tourism product, including; accessibility, accommodation, activities, attractions and amenities. Thirdly, it suggests that tourist destinations are increasingly attracting a wide array of travellers who may have different needs and wants.

\subsection{Defining Tourism}

Individuals become tourists when they voluntarily leave their normal surroundings, where they reside, to visit another environment. These individuals will usually engage in different activities, regardless of how close or how far this environment (destination) is (Hall, 2008; Holloway \& Taylor, 2006; Jafari, 2002). Therefore, tourists are visitors, and what they you do whilst visiting another place may be considered as tourism. Back in 1963, the United Nations Conference on International Travel and Tourism agreed to use the term 'visitors' (other than residents) to describe individuals visiting another country. This definition covered two classes of visitor: Tourists were classified as temporary visitors staying at least 24 hours in a destination. If they are travelling for recreation, health, sport, holiday, study or religious purposes, their visit could be categorised as leisure. Alternatively, excursionists, including cruise travellers may be considered as temporary visitors, if they stay in a destination for less than 24 hours. However, these definitions fail to take into account the domestic tourists. In 1976, the Institute of Tourism (which later became the Tourism Society) suggested that tourism is the temporary short-term movement of people to destinations outside the places where they normally live and work. Therefore, tourism includes the movement of people for all purposes, including day visits or excursions (Cooper, 2008; Holloway \& Taylor, 2006).

This broader definition was slightly reformulated at the International Conference on Leisure Recreation Tourism that was organised by the Worldwide Network of Tourism Experts (AIEST) and the Tourism Society in Cardiff, in 1981: "Tourism may be defined in terms of particular activities, selected by choice, and undertaken outside the home environment. Tourism may or may not involve overnight stay away from home”. In 1991, the United Nations World Tourism Organisation declared that "Tourism comprises the activities of persons travelling to and staying in places outside of their usual environment for not more than one consecutive year for leisure, business or other purposes". At this stage, one could differentiate 
between domestic and international tourism (Yuksel, 2004). The former refers to travel that is exclusively undertaken within the national boundaries of the traveller's home country. The latter refers to travel within the borders of one's home country. Domestic travel will have an impact on the balance of payments and will reduce the outflow of money from the tourists' home country (Mathieson \& Wall, 1982).

\subsubsection{The Nature of Tourism}

At this stage, it is important to realise that there are two types of travellers: There are those who travel for reasons of business. Others may travel for personal motives, including visits to friends and relatives (VFR travel); study; religious pilgrimages; sport; health, et cetera. For the first group, the decision to travel, and where to go, is largely beyond their control. The business travellers will have little discretion in the choice of their prospective destination, or on the timing of their trip. Generally, the purpose of their trip is not to enjoy the destinations' attractions and facilities. Business travel is usually arranged at short notice and for specific and brief periods of time; the duration of their itinerary may often be as short as a day (Swarbrooke \& Horner, 2001). In this case, there could be a substantial journey time involved. For these reasons, business travellers need the convenience of frequent, regular transportation facilities, efficient, reliable services and good accommodation facilities (in terms of accommodation and catering) of a high standard, at their destination (Jafari, 2002). Very often, business travellers will be less concerned about the cost of travel, as their employer could be paying for their travel arrangements (Gustafson, 2012). Higher prices will not deter them from travelling, nor will lower prices encourage them to travel more often. Therefore, there seems to be inelastic demand for business travel (Gillen, Morrison \& Stewart, 2003; Brons, Pels, Nijkamp \& Rietveld, 2002; Arnott, De Palma \& Lindsey, 1993). On the other hand, leisure travel is highly elastic for those travellers who are price-sensitive. The lower prices for holidays to particular destinations will usually lead to an increase in the aggregate numbers of travellers (Hall, 2008). Frugal tourists will usually shop around for affordable holidays (Xiang, 2013). Therefore, they may be prepared to delay their travel, or to book well in advance of their travel dates, if this would translate to a significant reduction in their travel costs (Russo, 2002).

The growing disposable income among many populations from developed and developing countries is having an effect of reducing price elasticity for many holiday makers, as upmarket winter sports holidays, cruises, special interest and long-haul travel continue to attract a greater proportion of travellers (UNWTO, 2017). 


\subsubsection{The Ability to Travel}

Beyond price, there are other reasons why specific tourism products (for example airline service or certain types of holidays or resorts) are chosen, as opposed to others. The demand for tourism is dependent on whether the potential traveller has the ability to travel (i.e. travel facilitators) or the desire to travel (i.e. travel motivators). Leisure time and disposable income are two of the most important travel facilitators in tourism. They are called facilitators because they are factors that may actually facilitate or enable individuals to travel. There are other factors that may also affect the persons' ability to travel. Alternatively, these may limit the ability to travel. These factors include;

- Age can affect the ability to travel either through health restrictions, or through financial limitations;

- Stage in the family life cycle: Travellers may have the money and the time at their disposal, but family commitment may preclude travelling;

- Political stability and peace: Although this issue may not prevent travelling; it may limit the tourists' choice of destinations. There may be restrictions that may be imposed on nationals of some countries for political reasons, including; conflicts, wars or acts of terrorism.

Different people will consider different qualities in destinations. For example, individuals may value sporting facilities, others may prefer social life and night clubbing. Travel for leisure and pleasure could involve a wide range of human emotions and drives that may be difficult to explain. However, the motivations to travel relate to the individuals' will to travel. The motivators are the factors which could explain why people do what they do, they also seem to justify the individuals' behavioural intention. They are intrinsic, and could relate to the human beings' inner feelings, emotions and beliefs, as they arise out of need and wants. Motivators may be conscious and subconscious and are often deeply embedded in one's psyche. Tourism planners, developers and promoters need to identify why people choose to travel, when some necessity compels them to do so. What motivates them to travel to a holiday destination? It is obvious that tourism satisfies some human needs. The question is, which ones? The travel motivators may be divided into four categories, as featured in Table 1.1.

Undoubtedly, a large number of people wish to travel. Therefore, the tourism industry has a vested interest in determining: What motivates individuals to travel? What motivates them to 
engage in specific tourism activities, and to choose one destination as opposed to another? The prime motivation to engage in pleasure travel is the desire to be elsewhere, even temporarily from the routine constraints and stresses of everyday life.

Sharpley (1994) contended that the motivation to travel may be attributed to extrinsic or intrinsic factors. Extrinsic tourist motivation is often influenced by a need to escape from the pressures and conditions of life in a tourist's home society. Therefore, the need for tourism could have been developed from the individuals' anti-thesis to work. Conversely, the individuals' intrinsic motivation to travel may arise from deep-rooted, psychological needs, such as self-esteem, or a need for companionship. Sharpley (1994) held that the tourists' motivation results from a variety of social, economic, demographic and psychological factors that are peculiar to each individual tourist. The author went on to suggest that these factors are not constant and may change through time.

\begin{tabular}{|l|l|}
\hline \multicolumn{2}{|l|}{ Table 1.1 Travel Motivators } \\
\hline Category & Motivations \\
\hline Physical & $\begin{array}{l}\text { Refreshment of body and mind for health purposes; participation in } \\
\text { sports; pleasure (or fun); excitement; romance; shopping and } \\
\text { entertainment; among others. }\end{array}$ \\
\hline Cultural & $\begin{array}{l}\text { Curiosity about foreign countries, people and places; interest in art, } \\
\text { music, folklore and architecture; interest in historic places (remains, } \\
\text { monuments and churches); experiencing specific events (for example } \\
\text { Olympic Games, et cetera); among others. }\end{array}$ \\
\hline Personal & $\begin{array}{l}\text { Visiting friends and relatives; meeting new people and seeking } \\
\text { friendships; seeking new and different experiences in different } \\
\text { environments; escaping from one's own permanent social } \\
\text { environment (desire for change); personal excitement of travelling; } \\
\text { visiting places and people for spiritual reasons (including } \\
\text { pilgrimages); among others. }\end{array}$ \\
\hline Prestige and Status & $\begin{array}{l}\text { Pursuit of hobbies; continuation of education and learning; seeking of } \\
\text { business contacts and professional goals; conferences and meetings; } \\
\text { ego enhancement and sensual indulgence; fashion, keeping up with } \\
\text { others, et cetera. }\end{array}$ \\
\hline
\end{tabular}




\subsection{The Tourism Product}

The tourism industry's major function is to serve travellers. Its success depends on the positive inter-relationships of all sectors. It is hoped that this synergy among tourism service providers will translate to a positive experience to the individual tourist. Basically, tourism comprises four main sectors: (i) Transportation (ii) Accommodation (iii) Ancillary Services and (iv) Sales and Distribution.

Tourism would not exist to the extent that it does today if tourists are not able to travel from one destination to another, in a quick and efficient manner. Transportation is what makes this possible. The transportation available to the tourist can be divided into air, water and land. The tourists' need for transportation can be divided into three groups: transportation from the point of origin to the host country (destination) and return; transportation between host destinations, where tourists travel to more than one destination; and transportation within host destinations.

Generally, air travel will be used to reach distant destinations. For the shorter distances, tourists may travel by car, by train and sometimes by boat. Travel between host destinations could be undertaken by air, although this may well depend on how far they are from their country of residence. Different means of transportation are normally used within host destinations. Frequently, tourists would like to experience different forms of transportation, which often add colour to their overall tourism experience. Many countries offer unusual forms of transportation including cable cars, funicular railways, monorail, punting, jet-boating and rafting, among other options. These alternative transport vehicles are an attraction within themselves. For instance, the Emirate of Dubai is currently evaluating the construction of a fast transport link through a hyperloop system that could potentially reduce travel times to tourists and residents alike. The hyperloop's vacuum-sealed pod transportation system is a futuristic passenger and freight transport system. Its promoters allege that this innovative technology could reach nearsupersonic speeds. 


\subsection{Transportation}

\subsubsection{Air Travel}

Air transportation can be separated into national (or domestic) and international flights. Domestic flights depart from one point to another within the same country. International flights depart from a point in one country to a point within a different country. Travellers may travel through public or private companies. Airlines may offer scheduled, chartered, low-cost, commuter or regional services, operating to / from their country. Very often, they may also have smaller airlines which operate air taxi services, non-scheduled services and sight-seeing tours.

\subsubsection{Scheduled and Chartered Services}

The scheduled and chartered tour arrangements may have fixed itineraries as transportation service providers are expected to operate regardless of the numbers involved. Yet, in times of disruption or in any emergency, scheduled services usually accommodate distressed passengers, other than chartered services. The main difference between scheduled and chartered services is price. The majority of tourists who prefer to pre-organise long distance travel arrangements may usually opt for scheduled transportation, for this purpose. This is where the selected means of transportation operates according to a fixed timetable. Therefore, the scheduled flights will operate regardless of numbers.

The charter flights which encounter technical or other problems may not have the same ability to meet the needs and wants of their passengers. The chartered service is usually cheaper as the producer of the tour is able to negotiate better prices for the charter of a whole aircraft and / or for large block bookings at hotels.

\subsubsection{Legacy Airlines}

National airlines (also known as legacy carriers) carry the bulk of the world's scheduled air traffic under the flags of over one hundred nations. For example, American, Delta, United, Air Canada, Aero Mexico, British Airways, Lufthansa and Qantas would be considered legacy carriers. Many of these flag carriers have a long history, as they may have started their operations in the first half of the $20^{\text {th }}$ century. They may also be considered as full-service carriers (particularly during long-haul journeys, where they provide in-flight service). They 
typically own a broad and varied fleet, with many different types of aircraft. Usually, these airlines may have an extensive route network, as they operate to domestic and international destinations. A trend among legacy carriers is to outsource short-haul and medium-haul flights to regional airlines.

Legacy airlines started differentiating their product as they created and innovated many of the comforts on board their aircraft, including; the inflight entertainment that passengers enjoy while travelling. Many legacy airlines offer a multitude of higher-end travel services and could even offer airport lounge facilities, among other services. They may offer these services as they collaborate with other airlines through partnerships and codeshare agreements, alliances and mergers.

Full-service, legacy carriers may be equated with 5-star hotels which offer complete luxury for their guests' sumptuous experiences. The 5-star hotels offer many facilities, hire many employees and offer posh real estate as opposed to smaller hotels. Moreover, the smaller hotels may not be located in best location. They may have less employees, as most services are do-ityourself. The low-cost hotels may offer only basic facilities to their guests.

\subsubsection{Low-Cost Carriers}

The concept of low-cost carriers (LCC) is based on the idea of delivering low fares to induce demand. Attaining low-cost requires high efficiency in every part of the business. Therefore, the key components of the LCC business model are the following; high aircraft utilisation; no frills, including; no inflight entertainment, no business-class seating, the use of a single type of aircraft, the aircaft cabin interiors may be fitted with minimum comforts, no seat-back video screens, no reclining seats and blinds. These airlines may choose to carry advertising inside the cabin to increase revenue. Meals and beverages are usually paid for in full. Moreover, LCCs may typically cut overheads by flying to / from more remote airports (with lower access charges). Some airlines also extend the definition of "frills" to include standard services and conveniences; for example, a no-frills airline may charge passengers additional fees for checkin luggage, for using airport check-in desks, or for priority boarding, among other services. LCCs keep their costs down as they do not print their own tickets. Passengers are also encouraged to check-in online. Moreover, LCCs may be strict when it comes to no-show guests, as they do not allow cancellations. and may not offer refunds for missed flights. 
LCCs' processes are kept as simple and straightforward as possible. They usually operate a single type of aircraft. This way, pilots, flight attendants, engineers, mechanics and operations personnel are specialised in a single type of aircraft. This means that there is no need for costly re-training of staff to operate different types of aircraft with their own specifications, and for maintaining an extensive inventory of spares.

\subsubsection{Legacy versus Low-Cost Carriers}

For the time being, passengers could not combine their low-cost travel arrangements with other legacy airlines' reservations. LCCs operate a simple point-to-point network, unlike the legacy carriers who will usually provide onward connectivity options through other airlines. If they have more than one travel itinerary that includes a low-cost carrier, they could not have their luggage labelled and passed from one flight to another (as it is the case for legacy airlines). Unlike the full-service carriers, LCCs do not use the same Global Distribution Systems (GDSs), which are very costly. LCCs have kept their distribution channels as simple as possible. They usually sell their tickets through the internet (Buhalis \& Law, 2008), via their website or via price comparison sites, like Kayak, Google Flights and Momondo, among others. Their fares are usually paid by credit cards and debit cards. LCCs may not utilise many sales offices and they do not rely on the travel agents' services. This allows them to save costs, which are usually reflected in their prices. However, LCCs would usually contract specialised call centres for telephone sales and customer service issues.

\subsubsection{Water-borne Transportation}

There are many forms of water-transportation, including ocean cruises, ferries and hovercrafts, passenger cargo ships, river cruises, house boats and yacht charters. Cruising in particular has staged a revival after many years of decline. Whereas cruises are designed for pleasure, ferries provide a necessary means of water transport for both passengers and cars, over short distances. Recently, short-sea (ferry) vessels have also achieved new levels of comfort and speed on many routes. Technological developments have helped to reduce high operating costs, while new forms of water transport have been developed, such as hovercrafts, jet foils and the twin hulled catamaran ferries. 


\subsubsection{The Ocean Liners}

Line voyage services are those offering passenger transport on a port-to-port basis, rather than as part of a cruise. Ships supplying these routes are known as liners. Some former ocean liners operate as cruise ships, such as Marco Polo. However, their use is diminishing. The only dedicated transatlantic ocean liner in operation is Queen Mary 2 of the Cunard fleet. She also has the amenities of contemporary cruise ships and offers significant services like cruises.

\subsubsection{Cruising}

A cruise ship or cruise liner is a passenger ship that is used for pleasure voyages, where the voyage itself and the ship's amenities are a part of the experience, as well as the different destinations along the way, i.e., ports of call. Transportation is not the only purpose of cruising. In fact, many cruises return passengers to their originating port (this is known as a closed-loop cruise), with the ports of call that are usually in a specified region of a continent. The cruise ships are divided in the following categories:

- Traditional Cruises which provide a holiday at sea, sailing from and returning to the same port. This itinerary could last from 7 to 15 days with five or more ports of call.

- Fly cruises involve the transportation of passengers by air from a home base to join a cruise ship at a certain port. Afterwards when the cruise trip is completed the passengers will return by air to their origin.

- Cruise and Stay is a combination of a fly-cruise and ground arrangement, where the passengers stay some time in one of the ports of call.

- Mini-cruises are short cruises of 2-5 days duration and are often operated by car ferry operators during low season.

- Educational cruises include special lessons on board and often relate to a special interest of the passengers.

\subsubsection{Ferry services and new modes of crossing channels}

The term ferry is one which embraces a variety of forms of short distance, water-borne transport. This includes urban transport, in cities, where outlying suburbs and surrounding towns are reached by water. Ferries of this type also attract tourists, either as a convenient form of local transportation or as an original way to view the city. 
In spite of the introduction of new fast ferries, alternative and still faster forms of water transport are becoming popular on many short and medium range routes. With a certain degree of novelty, hovercrafts, hydrofoils and catamarans have improved water transportation services with benefits of speed and convenience. Hovercrafts rides on a cushion of air above the surface of the water. A hydrofoil is a lifting surface, or foil, that operates in water. They are similar in appearance and purpose to aerofoils that are used by aeroplanes. A catamaran is a multi-hulled watercraft featuring two parallel hulls of equal size. Catamarans range in size from small (sailings or rowing vessels) to large (naval ships and car ferries). The structure connecting a catamaran's two hulls range from a simple frame strung with webbing to support the crew to a bridging superstructure incorporating extensive cabin and/or cargo space.

\subsubsection{Other water-borne transport}

The attraction of water offers many other opportunities for tourist activity, both independently and in forms which have been commoditised and packaged for the tourist. Inland waterways, particularly; lakes, rivers and canals provide exceptional opportunities for recreation and tourism. Where there is a large river, there is normally some form of river cruising. Houseboats are usually found in canals or on rivers. These forms of accommodation offer flexibility for independent travellers who can navigate their own houseboat. They combine accommodation and travel on the waterways. Boat rentals and yacht charters are highly competitive businesses, particularly during the high season (i.e. in summer, as the weather permits).

\subsubsection{Land Transportation}

Travel on land gives a choice of travel by rail or road, with the latter offering travel by car, coach (or bus) and campervan.

Travel by rail is readily available in most parts of the world, and combined air-rail travel has become quite frequent. Generally speaking, trains offer two classes of service; first and second class. Long distance trains normally carry sleeping or couchette cars.

Cars are a popular means of transportation and these may be privately owned or rented. The increase in private car ownership has changed travel habits of tourists. For instance, the flydrive packages have adapted to the needs of the motoring tourists. Very often, car rental companies collaborate with airlines as they offer services, such as: rental locations at most 
airports; rent-it here, leave-it-there systems (often referred to as one-way rentals); free worldwide reservation services with no cancellation fees; chauffeur driven services in many countries; and special "unlimited mileage" plans. In addition, taxi services are provided in all major cities in all continents.

The hotel and catering industry responded to these developments by building motels and hotels, roadside cafes and restaurants along transport routes as they benefited from accessibility.

\subsection{Accommodation}

The accommodation sector comprises different forms of hospitality facilities which can be conveniently categorised as service (where catering is included) or self-catering establishments. Service accommodation may consist of hotels, bed and breakfasts (B\&B's), travel inns, and the like. Whereas self-catering accommodation may include; campsites, caravans and holiday rentals of villas, apartments and chalets, among others. Half-board accommodation will usually include breakfast and dinner, whilst the full-board service will involve the provision of lunch, as well. Hotels are the most significant and widely recognised service providers of overnight accommodation for tourists and business travellers. They may also form one of the key elements of package holidays.

Historically, accommodation was established along major transport routes, particularly where there are cross-roads. Subsequently, hotels were developed close to railways and airports. The accommodation which is situated close to major transport routes is designed to serve the transit market (i.e. people who are on their way to somewhere else). On the other hand, those tourists on vacation will generally want to stay as close as possible to the major centres of tourist activity (for example; near the seaside or in close proximity to the mountains, country towns, health spas or major cities). If the major attraction is the sea, tourists will want to stay as close to the sea as possible. For example, hotel guests may be willing to pay a premium price for a room that is located in the sea front. The business travellers may require accommodation which is close to their business activity. Whilst location is generally considered the most critical factor with regard to the profitability of an accommodation unit, other factors, such as price and facilities are also deemed important in the hospitality sector: 
Price could be a limiting factor for many leisure travellers. At times, it may also place restrictions on the choice of accommodation. Many tourists travel on a budget. Therefore, they may only consider accommodation that is affordable to them (i.e. if it is within their price range). The size of the hotel establishment can also be considered as a crucial aspect of the hospitality product. Some individuals consider large hotels to be impersonal and "cold". Therefore, they may opt for smaller units. Others may perceive that the larger hotels are more likely to provide a guaranteed minimum level of service. The hotel amenities can also prove to be a very important criterion for tourists, particularly to the business travellers who may require certain specialised services.

\subsubsection{Hotel Brands and the Corporate Chains}

With the development of mass tourism, so have the large hotel chains and corporations within the accommodation sector. This expansion has also been aided by franchising, whereby hotels and motels are increasingly being operated by individual franchisees who are paying royalties to their parent companies, for the privilege of operating under their brand name. This form of expansion has been used with great success around the world as chains market their products more aggressively, advertise extensively and work closely with large tour operating organisations. In addition to their own websites, they provide an effective distribution network that is linked to global distribution systems, they tend to a have a higher presence in the industry than their market share would suggest.

Leading chains around the work have often diversified their brands by price and image to appeal to a wider variety of markets. International hotel chains retain a strong hold on the global accommodation market. Their policy is to create an international and uniform marketing image to distribute their product around the world.

A recent trend among hotel chains has been the development of budget-price properties. For example, in mainland Europe, Accor Hotels has exploited the deficiency in this sector by introducing the super budget chains, 'Formule 1' and 'Ibis Budget'. While others have popularised low budget brands such as bed and breakfast (B\&B) hotels (for example, Britain's Premier Inn). These very low-priced hotels have managed to reduce costs by developing a unitary design as they automated many of their services. Super budget hotels, including Easyhotels offer very basic rooms, which may be quite small. The rooms may offer TVs (at a premium) and small showers and toilet cabinets. However, they may lack wardrobes or even 
bed side lights. They may not have communal areas or bars, and housekeeping services are usually charged. Sales are exclusively online and they may not advertise their properties. Moreover, no discounts are given to distributors, such as travel agents or tour operators.

\subsubsection{Consortia}

In an effort to counteract the distribution strengths of large chains, many independent hotels around the world have frequently banded together to form consortia. While this strategy may allow the group to benefit from economies of scale, such as mass purchasing, it reinforces their marketing strength. It enables them to improve their distribution through a united website. Therefore, consortia may benefit from websites of other leading suppliers, including travel search engines. While many of the larger consortia such as Best Western Hotels and Resorts and Inter Continental Hotel Group operate on a global scale; others may operate on a national scale. Some privately-owned hotels have even united within a themed consortium, in order to market themselves more effectively at home and abroad. For instance, Choice Hotels International has established a strong national brand in overseas marketing. This is a highly appropriate strategy when developing a niche approach. For example, Small Luxury Hotels of the World focus on building an image of high standards, yet they strive to deliver a personal service. While Grand Heritage Hotels, an American owned consortium which is now drawing membership from high graded UK hotels emphasise luxury and status. Other specialist consortia operating in the UK include: Pride of Britain Hotels, Scotland's Personal Hotels and Great Inns of Britain, among others.

\subsubsection{The Bed and Breakfast $(B \& B s)$}

Tourists may want to meet and engage with the local people. They may enjoy an intimate relationship with the culture of the country they are visiting. For this reason, they may choose to seek accommodation in guesthouses or bed and breakfasts (B\&Bs). These forms of accommodation establishments are generally family-run, and they may cater to leisure as well as business tourists. B\&Bs in particular provide a very valuable service to the industry, in that they can offer the informality and friendliness that is sought by many tourists. Many of these small establishments (which may not have more than three bedrooms) would usually provide accommodation to holiday makers who are touring by car. 


\subsubsection{Farmhouse Accommodation and Agri-tourism}

Farmhouse holidays have also enjoyed considerable success in recent years. European countries with strong agricultural traditions have catered for tourists in farmhouse accommodation for many years. Farmers have often turned to tourism as a means of boosting revenue, particularly during the off-peak season. The simultaneous trend to healthier lifestyles and an increased appeal on natural foods and the outdoor life have also helped to make farm tourism popular among tourists. As a result, many tourist boards have provided assistance and training to those farmers who were interested in expanding their accommodation for tourism purposes. For example, both Ireland and Denmark have been packaging modestly priced farm holidays for the international market, in association with international tour operators and major ferry companies. In the case of Denmark, this has been a logical development to attract price sensitive tourists to what is generally perceived as an expensive destination.

\subsubsection{Camping and caravanning}

Camping is one of the most popular outdoor recreational activities for many tourists. In 2015, the revenue from campgrounds and parks was estimated to reach around 5.8 billion U.S. dollars. Recreational vehicles including caravans are also a popular and convenient way of camping. These vehicles provide campers with home comforts such as kitchen facilities and living areas.

\subsubsection{Second Homes and Time-share Accommodation}

Second homes may be used for seasonal, recreational, or occasional use. Alternatively, second homes may be described as properties that are owned or rented on a long lease. No doubt. the growth of second-home ownership has had an effect on the tourism industry.

Time-share is a specialised form of "vacation ownership" as it is associated with the ownership of a property. Multiple users will usually hold rights to use the property. Each sharer is allotted a specific period of time to use the property (typically, the duration of time-share accommodation is of one week, at the same time of every year). Therefore, the accommodation units may be partially owned on a lease, or may have a "right-to-use". The sharer holds no claim to ownership of the property. Timeshare offerings may be structured through deeded interests, right-to-use, club membership, share-based plans, et cetera. 


\subsubsection{Educational Accommodation}

Educational accommodation, including; universities and other institutions of higher education may often rent their students' rooms during the summer months. The students' accommodation is usually situated near major tourist destinations, such as London, Cambridge, Oxford and Edinburgh, among other university cities. Several universities have experienced considerable success in this venture and have further expanded their involvement with the leisure market; by providing essential facilities that reflect the standards of budget holidaymakers.

\subsubsection{The AirBnB Model of Shared Accommodation}

The Sharing economy describes economic and social activities, involving; online transactions in an open-source community. It usually refers to peer-to-peer sharing via an online market place. The sharing economy may take a variety of forms, including using information technology to provide individuals with information, that enables them to optimise resources through an effective use of excess capacity. Airbnb is a good example of an online marketplace which enables individuals to lease or rent their accommodation. Airbnb allows online visitors to book accommodation for entire homes, private or shared rooms. Online users can filter their search results according to their affordable budgets. Moreover, Airbnb's user-friendly website allows its users to choose particular amenities, facilities and other options, which will suit their requirements. This form of "shared" accommodation is usually cheaper than hotels, particularly in urban areas. AirBnb does not own any accommodation; it is merely a broker and receives commissions from both guests and hosts, in conjunction with every booking.

\subsection{Ancillary Services}

Most tourists on holiday will want to be amused, entertained and active during their visit. In this case, they will require information on their destination's ancillary services, including activities and attractions. Shopping, catering and wifi facilities are also important aspects of the tourism product. The access to business centres, interpreters, financial services and communication facilities may also be necessary requirements in tourist destinations. 


\subsubsection{Tourist publications and online content}

Tourists will require information about their prospective destination both before they leave home and once they arrive. This information should give details on the local people and their way of life, language, currency, climate, amenities, transportation, accommodation and attractions. The tourists are unable to see, touch or feel the tourism product in advance. Hence, the supply of such material is critical to the success of any tourist destination. The content marketing of the destinations could be a deciding factor as to whether tourists will visit them or not. The provision of clear and informative material that is readily available online are considered as essential services to prospective visitors.

Today's travel marketers can increasingly impact their consumers through ubiquitous mobile devices, including smart phones and tablets. The usage of the mobiles has changed the consumers' attitudes, expectations, and even the way they buy hospitality products and travel related services. Local and "near me searches" have changed the travel path to purchase with in-destination or "in the moment" sales opportunities. Consumers expect the "mobile first" user experience with easy access to contact information, maps, directions and reviews. They expect accuracy in listing information, and immediate responses from brands.

\subsubsection{Public Service and Amenities}

A destination's infrastructure is not usually developed with the tourist in mind, but should include facilities and services that are required by tourists. Infrastructural elements include; roads, electricity and water supplies, communication facilities, sewage and waste disposal, policing and security, medical services and hygiene. In developed countries, these facilities are provided for residents. However, if a region has tourist potential, its infrastructure must take into account the likely needs for future expansion, due to a possible influx of tourists.

\subsubsection{Financial Services}

Tourists require access to financial services in order to fund their travel arrangements. Foreign exchange is probably the most important service required; tourists may also need insurance and credit facilities.

Insurance is an important service and could be an obligatory aspect of a tourist's travel arrangements. Travellers may need coverage for one or more of the following contingencies: 
medical care and hospitalisation (and where necessary, repatriation); personal accident; cancellation or curtailment of holiday; delayed departure; baggage loss or delay; money loss and personal liability, among other products. Some policies may also include coverage for the collapse of the travel agent or tour operator (who sold the tourism products).

Travellers today have an ever widening choice of how they could pay for travel services and goods while abroad. These include carrying foreign cash, in the form of banknotes (yet, this may lead to loss or theft); by using travel vouchers, credit cards or debit cards. Travellers' cheques could be utilised in many parts of the world, as these products are sold by banks and commercial institutions. Travel vouchers may be used for the payment of travel services, including car hire and hotel accommodation.

\subsubsection{Food and Beverage}

For many travellers, the consumption of food and drink forms an important part of the travel experience. It is not unusual for the tourists' consumption patterns to change quite considerable whilst they are away from home. Many tourists gain great enjoyment from dining out, particularly, if they are not in the habit of doing this at home, whilst others may decide to consume convenience foods.

\subsubsection{Entertainment}

This category includes facilities such as cinema or movies, night clubs, theatres, plays and shows. As a general rule, they are often attended for the sole purpose of filling in the night time hours rather than being part of a planned itinerary.

\subsubsection{Retail Facilities}

Shopping can be seen as an attraction for some tourists, or it may be considered as a basic facility that tourists expect. The retail trade provides an important service to the tourist, in terms of supply. Tourists may need to purchase basic necessities such as toiletries, or may want to purchase souvenirs and gifts which reflect the destination they visited. Moreover, the purchase of duty-free goods at airports; or on on-board ships and aircraft; or at specially designated dutyfree ports have been in demand by tourists, for a long time. 


\subsubsection{Education and Training}

With the growing institutionalisation of tourism industry sectors, there is a greater emphasis on professionalism. In many countries, many professional bodies have introduced their own programmes of training and vocational education, which are often carried out through full time or part time courses at local colleges of further or higher education. Examples of these, include courses offered by the Institute of Hospitality, formerly known as the Hotel Catering International Management Association (HCIMA), the Chartered Institute of Transport (CIT) and the Institute of Travel and Tourism (ITT). In-service training for travel agents was first formalised with the introduction of the Certificate of Travel Agency Competence (COTAC), nationally validated by the City and Guilds of London Institute (CGLI) and supported by ABTA's National Training Board (now known as TTC training). Certificates in Travel (for travel agents) and Tour (for Tour Operators) replaced the former ABTA-approved ABTAC and ABTOC qualifications, but all too briefly (Holloway \& Taylor, 2006).

Many universities in the world are increasingly introducing undergraduate degrees in travel and tourism. These higher education or vocational institutions are joining the already well established higher national diplomas, post graduate diplomas and master's degrees in the subjects of tourism and hospitality management. The popularity of degree level tourism programmes has led to a huge expansion of courses on offer. Recent trends have led to the establishment of more specialised degrees, including masters' degrees. Leading universities in hospitality and tourism management, include: Hong Kong Polytechnic University, Griffith University, the University of Queensland, Pennsylvania State University Loughborough University, University of Surrey, Purdue University (West Lafayette), Virginia Polytechnic Institute and State University, Bournemouth University and the University of Birmingham, among others (ARWU, 2017).

\subsubsection{Tourist Guides and Courier Services}

There is no specific term which will conveniently identify those individuals whose function is to guide, inform and engage with groups of tourists. Whilst some tourist guides and couriers may be employed by carriers and tour operators, others may work independently or could provide freelance services to companies in the industry. 


\subsection{Sales and Distribution}

In addition to the above mainstream sectors, there is a side of the tourism industry that is related to the provision of support services. In tourism, the consumer is nearly always moved to the product as opposed to a product being moved to the consumer (which is the case with most other services). The tourism product and the consumer are usually separated by geography, as they may be situated in the opposite sides of the world. The system by which a tourist product is sold to the tourist is known as the sales distribution system. In common with most other industries, the tourism sales distribution is carried out through service providers (including; airlines, hotels, transportation companies, et cetera), wholesalers (tour operators) and retailers (or travel agents), both being known as intermediaries, or middlemen. In this day and age, consumers are increasingly purchasing tourism products through digital media (Schegg \& Stangl, 2017). Therefore, many service providers and tour operators are selling directly from their corporate web sites, or through travel search engines (where online visitors may compare prices).

In tourism, the producer (or manufacturer) equates with the supplier of service (i.e. the supplier of the transportation, accommodation or ancillary service). The wholesaler is known as the tour operator or tour wholesaler. The retailer is known as the travel agent. The suppliers are those organisations which provide the actual components of the tour (for example an airline will provide air transport; a hotel will provide accommodation and a motor coach company will provide surface transportation and some sightseeing arrangements). Other suppliers include organisations that offer activities (for example; trekking, jetboating, rafting and surfing, et cetera) and those that offer attractions such as theme parks, live-theatres, museums and the like.

The wholesalers are the tour operators who may also provide complete tours for sale, i.e. including transport, accommodation and land arrangements (these may be components of inclusive tours). Traditionally, tour operators have been classified as either inbound operators or outbound operators. Inbound operators arrange and package holidays for tourists entering the country in which the tour operator is based, whilst the outbound operators arrange and package tours outside of the country from where they are based (i.e. overseas). The retailer is the travel agent who sells the tours to the consumer. 


\subsubsection{Travel Agency Operations}

Generally, the travel agents' job is to work out an itinerary that suit their customers' requirements in order to secure reservations from them. This can be achieved by either working through a tour operator or by approaching individual suppliers, directly. The travel agents are usually paid commission by the supplier / tour operator for sales made on their behalf. However, many airlines have either reduced their commissions (to travel agents) or eliminated them, completely.

The travel agents secure specific elements of the tourism product to meet their client needs. Therefore, the travel agents provide a location (either through brick and mortar premises, or online) where potential tourists can seek information on the tourism products;

- Travel advice on the various options available;

- A booking service to secure reservations, on the various aspects of the product, such as transport, accommodation, sight-seeing, et cetera;

- Support in travel formalities. This may include the procurement of travel documents, including passports and visas;

- The issuance of tickets, vouchers and itineraries for all travel arrangements.

A passport (or identification document) is required to travel internationally, and in some cases a visa may also be needed. The inability to get these documents may hamper the individuals' ability to travel, at least internationally. Moreover, some destinations may have currencies that could not be exchanged in other countries. Alternatively, individuals may have certain restrictions on the transfer of their funds. These issues may restrict international travel, although they could boost domestic tourism.

\subsubsection{Types of Tours}

The tour is one of the most often used words in the travel industry. It is also one of the most confusing because of its different meanings. To one client it may mean an itinerary that is advertised in an attraction brochure. To another, 'tour' may simply mean visiting a city or a tourist attraction during a trip. In many cases, tours are put together by retail agents who will then obtain actual components of the tourism product; directly from suppliers or through local tour operators. These tours can be customised to suit the individual clients' requirements, or 
they may be prepared in advance and marketed by the retail agent. In these cases, the retail agents act as tour operators and can either sell tours through their agency, or sell them through other retail agents. Likewise, tour operators may sell directly to consumers as they may have their own front offices, or a user-friendly web site.

An itinerary may be independent or packaged. A package tour, for which the official term is 'inclusive tour' is an arrangement where transport and accommodation services are purchased by the tourist, at an all-inclusive price. The inclusive tours have the following characteristics: the travel arrangements are planned in advance; they may include transport, accommodation and surface arrangements; they are sold at an all-inclusive price, covering all features included in the tour; and must be paid in full prior to departure.

Inclusive tours can be divided into independent inclusive tours (IITs) or escorted inclusive tours (or group inclusive tours - GITs). The independent tours are designed for individual travel and can be completely or partially tailor-made, to suit the clients' needs. The itinerary may be flexible or may be fully planned in advance. The escorted tours have all the components of the independent, inclusive tour. However, they also offer the services of a qualified tour escort in addition to the normal arrangements. These tours are usually arranged for groups of people who will travel together throughout the tour.

Tours which only provide a combination of accommodation and other activities within the same city or area are known as package tours or packages. The actual arrangements are usually quite flexible and may provide several choices of hotels, restaurants and other activities. Inclusive tour charters (IT charters) are charter flights combined with land arrangements. This arrangement is usually made available to the consumer at fixed, all-inclusive prices, through retail agents. Cruises and rail tours can also be classified as tours because they provide the various components that are normally associated with tours, i.e. transportation, accommodation and some surface arrangements. All-inclusive tours can be formed by combining several packages and / or tours to form a complete itinerary. For example, tourists can fly to a destination and join a cruise. Afterwards, they may decide to purchase a tour to visit local attractions near the port, before returning to their cruise. 


\subsection{Tourism Organisations and their Stakeholders}

Whilst the transportation, accommodation and the provision of ancillary services relate to supply of the tourism product; the sales sector is involved with demand. Therefore, retailers and tour operators have to deal with what their customers want. The first three sectors are concerned with supplying the traveller a specific service. These sectors may operate independently or they may collaborate together. For example, a hotel will probably rely on guests arriving by some mode of transportation. Likewise, suppliers of activities and attractions may also require a transport operator to get visitors to their location. Hence, in many cases there is scope for the tourism businesses to forge a close relationship with other service providers.

Moreover, the tourism industry would not operate efficiently unless there is some form of regulation and structure. The tourism industry participants may represent the government (for example national authorities, including tourist offices and agencies) or the private sector as they may be direct providers of tourist facilities or services, support organisations or development organisations. Their interests may be international, national, destinational or sectorial. At an international level, the geographical scope of an organisation may be either worldwide (for example, the World Tourism Organization - UNWTO) or restricted to a specific region of the world (for example, the Association of European Airlines). Whilst at a national level, the organisation's interest may be local or regional. Examples of these organisations may represent; surface transport sectors, hotels and other accommodation units, tour operators or wholesalers, travel agents, or training bodies).

\subsubsection{National Tourism Offices}

National governments usually establish tourist offices or tourism authorities to serve national goals in the realms of tourism planning and development. The tourism offices strengthen the public and private partnerships in international tourism marketing. Moreover, they may have an important regulatory role. Specifically, their responsibilities include;

- The promotion and advancement of the tourism destination;

- To advise government on tourism operations and to issue licenses;

- To contribute toward the improvement of the level of human resources in the tourism industry. 
- To advise government on the planning and development of the tourism industry, as well as on the infrastructure supporting the industry.

- To assist and advise on any tourism-related issues and to undertake activities, events and projects to improve the tourism product (MTTA, 1999).

\subsection{Tourist Destinations}

We have already seen how the four sectors of the tourism industry work, and we also looked at the tourism product. We have identified how tourism sectors rely on each other to provide those ingredients the travellers are looking for.

\subsubsection{Key Elements of Tourist Destinations}

Regardless of how or why individuals travel, there are some fundamental requirements that travellers' expect from destinations. Tourism researchers and developers say that there are several key elements that are essential to the success of a tourist destination. These are traditionally referred to as the 5A's - including; access, accommodation, attractions, activities and amenities.

Access: For a destination to be viable to tourists, there must be some way to get to the country, the region, and the various attractions. This does not mean that there has to be first class or mass transportation available to everything, but it does mean that access must be made possible. Access relates to transport but it can simply refer to a walking trail or a cycling track.

Accommodation: If tourists are to be more than just one-day visitors, they must have somewhere to stay. It is important for tourist destinations to offer a wide array of accommodation facilities, in terms of different price ranges. Sometimes, the accommodation is virtually part of the attraction of the destination, especially if it overlooks a spectacular scenery or landmark.

Attractions: Tourists rarely travel to a destination simply for the sake to stay in particular accommodation establishments. They usually travel to see what the destination has to offer them in terms of what they can see, do and experience. The features that attract a person to a particular destination are known as attractions. Attractions can be natural wonders, man-made attractions, special events, cultural or historic sites, arts and crafts, sport, music or dance, 
unusual or unique flora and fauna, night life (et cetera). Attractions are many and diverse. Therefore, the wider the variety of a destination's attractions would possibly appeal to a large number of tourists.

Activities: Tourists may enjoy doing certain activities whilst at their destinations. These activities include; shopping, eating out, using sports facilities and engaging in outdoor recreational journeys (among other activities).

Amenities: The destinations' amenities include the provision of electricity and water, sanitary facilities, safe drinking water, roads, police and emergency services, postal and communication facilities, media, et cetera. Crucially, these structures ensure that the tourists stay safe and sound during their stay in a destination. Tourists need to have access to basic facilities to feel comfortable and secure.

\subsubsection{Different Types of Destinations}

Destinations possess tangible characteristics and consist of a number of physical attributes, including; attractions, amenities, buildings, landscapes and so on. However, the tourists' perceptions are less tangible, such as; the hospitality of the locals (for example, Gemutlichkeit), the atmosphere generated by being in particular event, the sense of awe, alienation, or other emotions that could be generated by specific destinations (Murphy, Pritchard \& Smith, 2000; Moutinho, 1987). Destinations have different appeals to different markets. Some individuals love crowds, others love isolation and find crowded places unbearable. The appeal of the destinations is varied as they offer immense opportunities for tourism to be developed in almost any country, and in any region; provided that they are targeted at the appropriate market (Hall, 2008).

Most of the destinations are managed to some extent, whether they are natural or constructed. The national parks are usually left in their natural state of beauty as far as possible. Nevertheless, they have to be managed through the provision of access, parking, facilities, accommodation (such as caravans and campsites), litter bins and so on. Broadly, we can categorise destinations by delineating them according to their offerings, as suggested in Table 1.2: Moreover, holiday destinations depend on their image and tourist perceptions (Beerli \& Martin, 2004; Echtner \& Ritchie, 1993). Very often, the destinations' image is often frozen in time and could no longer represent a true picture of the place. For as long as the tourists' 
perceptions remain positive, promotional bodies will seek to support these images in their advertising and promotion. Most well-known tourist destinations, like cities and beach resorts, may usually rely on the stereotypes which have been built over the years. 


\section{Table 1.2 A Non-Exhaustive List of Tourism Destination Categories}

Adventure Tourism may include active holidays, such as winter sports which are commonly associated with rural sites. Mountain resorts have often been developed to attract winter sports enthusiasts.

Culinary tourism or food tourism involves the exploration of food. This aspect of a destination may be considered as a vital component of the tourism experience. Very often, tourists will dine in local restaurants when they are on holiday. Various types of restaurant fall into several industry classifications based upon menu style, preparation methods and pricing. Additionally, how the food is served to the customer helps to determine this classification.

Cultural Tourism (or culture tourism) is concerned with the traveller's engagement with a country or region's culture. Tourists travel to learn about the lifestyle of other people. They may be interested in their history, art, architecture, religion(s), and other elements that helped them shape their way of life.

Ecotourism is a form of tourism that is related to the responsible tourism to natural areas. Its focus is on the conservation of the environment, including flora and fauna. At the same time, it is intended to improve the well-being of the local people as it characterised by its low-impact, small-scale tourism (rather than mass tourism, which is more commercial).

Educational Tourism: This may involve those tourists who travel to a destination for educational purposes. Very often, many students pursue specialised courses to learn foreign language(s) in tourist destinations.

Health Tourism may be offered by resorts and spas. They may be based in rural, seaside or urban areas.

Medical tourism involves those people who are travelling to obtain medical treatment in a different country. In the past, this term may have referred to those who travelled from less-developed countries to major medical centres that may be situated in highly developed countries (for treatments which may be unavailable in the tourists' home country).

MICE: Meetings, incentives, conferences and exhibitions (or meetings, incentives, conferences, and Events) is a type of business tourism involving large groups of travellers who are brought together for a particular purpose. Their itineraries are usually planned well in advance.

Religious tourism is a type of tourism, where tourists may travel individually or in groups for pilgrimage, missionary, or leisure (fellowship) purposes.

Rural Tourism includes lakes and mountain tourism, but may also comprise countryside touring, agritourism products, such as farm holidays, fruit picking, gardens, visits and stays in rural retreats, river and canal holidays, wild life parks and national parks, et cetera;

Seaside Tourism includes seaside resorts, natural beaches, rental of boats and jet ski, fishing itineraries, coastal footpaths, scuba diving, et cetera;

Sports tourism refers to travel which involves either observing or participating in sporting events.

Urban Tourism includes visits to cities, towns, capitals and the like.

Wine tourism refers to tourism that is related to wine tasting, consumption or purchase of wine. Wine tourism can consist of visits to wineries, vineyards and restaurants that are usually known for their unique vintages, as well as for their organised wine tours, wine festivals or other special events. 
The following section provides a good example of different destinations that are available in North America, including; outstanding national parks with spectacular sceneries, the vast expanses of countryside, the historic sites, and a wide range of cultural and recreational facilities (including transportation, accommodation and restaurants). All types of accommodation exist in many parts of the United States of America (USA) and Canada, ranging from modern deluxe hotels or resort complexes to simple boarding houses and wellequipped camping sites. Motorised vehicles offering built-in sleeping accommodation, cooking and hygienic facilities are very popular means of transportation and are comparatively cheap to hire.

\subsubsection{Major points of interest in North America, comprise the following attractions:}

Niagara Falls with their spectacular rapids of the Niagara river are situated between Lakes Erie and Ontario. This attraction can be visited either from Canada or from USA.

The Grand Canyon and the Painted Desert: This attraction is an enormous gorge with a depth of $1.6 \mathrm{~km}$ and a maximum width of about $30 \mathrm{~km}$. It is part of the Colorado River. Within the State of Arizona, there is a 'Painted Desert' as it has colourful petrified flora, including fragments of fossilised trees.

The City of New York has many monuments and structures, including the statue of Liberty, Manhattan skyline, Empire State Building, famous museums, Greenwich Village, Central Park, exciting theatres, movie houses, Broadway, opera, innumerable restaurants and one can find all grades of accommodation.

The Rocky Mountains: Stretching from Alaska through to Mexico, the Rocky Mountains provide Canada and USA with their most spectacular mountain scenery and views. There are many pioneer towns and abandoned mining center (ghost towns). Moreover, there are many national parks including Banff, Glacier and Jasper in Canada and Arches, Bryce, Zion, Mesa Verde and Yellowstone, among others in the USA. These places offer dedicated areas for camping, hiking, mountain climbing, fishing and skiing.

Hawaii is an all year-round resort island in the Pacific ocean. This destination enjoys good weather, superb beaches, water sports, surfing, yachting, fishing and gold. There are numerous hotels of all standards as well as many fine restaurants. One may also find good shopping 
facilities. There are live volcanoes on the big island of Hawaii and Haleakala Crater on Maui island amid lush tropical vegetation.

Disney Complexes: Fantasy worlds that were built for pleasure and relaxation purposes. They offer breathtaking exhibits and presentations that are all provided within great complexes, comprising hotels and restaurants. These theme parks are located in Disney World Orlando, Florida and Disneyland Los Angeles, California.

San Francisco: The city's attractions include the spectacular Golden Gate Bridge, Chinatown and the famous network of colorful cable cars. The centre's architecture is picturesque and offers good sea food restaurants.

Calgary organises a great stampede (including cowboy competitions, rodeos and wagon racing among activities). Nearby, there is a Dinosaur Provincial Park, at Drumeller. The city is also close to Banff National Park.

Bermuda: With its sub-tropical climate, superb golf facilities, good beaches and fine water sports coverage, this destination offers different grades of accommodation ranging from deluxe hotels through to boarding houses. However, tourists cannot rent cars on the island. Nevertheless, the island offers excellent bus and ferry services. Taxis are plentiful and reasonably priced.

Washington D.C. is the capital of the USA. With its Capitol building being the seat of Government, the Lincoln Memorial and the world-famous Smithsonian Institute are some of the attractions of the city.

There are many other attractions in North America. However, they are too many to mention in the context of this book. 


\subsection{Questions}

- Describe the difference between travel facilitators and travel motivators as they relate to tourism demand.

- Price, location and facilities influence the selection of accommodation. Briefly describe how each may affect the tourists' decision of where to stay?

- What are the functions of tour operators and travel agents?

- Name different types of tourist destinations.

\subsection{Summary}

The tourism product is composite in nature. It includes everything tourists purchase, see, experience and feel from the time they leave home until the time they return. Thus, it is the sum of all services, including; the provision of transportation, accommodation, attractions and activities, financial services, tourist publication and tour guides, among other things.

While it is important to identify different aspects of the tourism product, the emphasis must be on the fact that the whole is greater than the sum of its parts. In effect, this means that tourism products and sub-products are dependent on each other. The provision of one sub-product (transportation) may not be worthwhile if other sub-products are unavailable (for example accommodation). Basic facilities are of no use if attractions are not available and vice-versa. Moreover, a bad experience with one sub-product (accommodation) may affect a tourist's impression of another sub-product (a sight-seeing tour).

In conclusion, destinations should consistently provide high standards in the provision of their tourist services. It is extremely important that tourism service providers identify their travellers' needs and wants to ensure their satisfaction, at all times. 